\title{
Communication
}

[Comunicação]

\section{Association of number of tandem repeats in two important adhesins in Mycoplasma hyopneumoniae}

\author{
[Associação entre os números de repetições em tandem em duas importantes \\ adesinas de Mycoplasma hyopneumoniae] \\ L.F. dos Santos ${ }^{1,2}$, J. Alvarez ${ }^{1}$, A. Perez ${ }^{1}$, M.A.S. Moreira ${ }^{2}$, M. Pieters ${ }^{1} *$ \\ ${ }^{1}$ College of Veterinary Medicine, University of Minnesota, 1365 \\ Gortner Avenue, St. Paul, MN, 55108, USA. \\ ${ }^{2}$ Universidade Federal de Viçosa - Viçosa, MG.
}

\begin{abstract}
Mycoplasma hyopneumoniae (M. hyopneumoniae) is the cause of enzootic pneumonia in pigs, one important disease that generates losses in swine production worldwide (Thacker and Minion, 2012). The success of $M$. hyopneumoniae colonization in the respiratory epithelium depends on the ability of this pathogen to attach to cilia (Mebus and Underdahl, 1977). Reduction in the adhesion capacity due to genetic variation could lead to decreased infectivity, as the loss of some of the adhesion proteins may end up in a reduction of the adherence ability of the mycoplasma (Razin, 1999).
\end{abstract}

In $M$. hyopneumoniae the adherence process is mainly mediated by receptor-ligand interactions and adhesins like P97 and P146 (Ferreira et al., 2007). Repeat region 1 (RR1), a locus containing tandem repeats (TR) in the gene $m h p 183$ (P97) has been suggested as to be immunogenic and essential for ciliary binding (Wilton et al., 1998; Minion et al., 2000). The TR in RR1 can vary between strains and this variability can influence the ciliary binding (Wilton et al., 1998). At least eight repeats in RR1 have been suggested as needed for cilium binding, and three repeats are required for antibody recognition (Minion et al., 2000). In the gene $m h p 684$ (P146), the locus of the polyserine RR3 is of unknown function, although it is located in a P85 fragment that is associated with binding to porcine respiratory cilia and plasminogen (Bogema et al., 2012). Multiple-locus variable number tandem repeat

Recebido em 10 de maio de 2015

Aceito em 11 de junho de 2015

*Autor para correspondência (corresponding author)

E-mail: piet0094@umn.edu analysis (MLVA) of RR1-P97 and RR3-P146 has recently demonstrated to be a useful tool for typing $M$. hyopneumoniae variants (Dos Santos et al., 2015). However, the usefulness of this approach to investigate the association between the two loci at the regional level has not been assessed. Moreover, little is known about the possible association between TR in RR1-P97 and in RR3-P146. Therefore, the aim of this study was to describe the spatial distribution and genetic heterogeneity of $M$. hyopneumoniae based on the TR in both loci in Brazil, and to investigate the association between RR1-P97 and RR3-P146.

One hundred fifty two clinical samples, submitted to the Microvet Laboratory (Viçosa, MG, Brazil) during Jan 2013 - March 2014 for diagnosis of $M$. hyopneumoniae were included in the analysis. Samples originated from 42 different production systems ( $n=63$ farms) located in eight states in Brazil, which included the main pig production areas (Figure 1). Samples that tested positive for $M$. hyopneumoniae by PCR were submitted to the Mycoplasma Research Laboratory at the University of Minnesota for MLVA typing, as previously described (Dos Santos et al., 2015). The number of repeats in each locus were recorded and combined to yield individual MLVA types. Spatial distribution of MLVA types was explored using ArcGIS 10.1 SP1 (ESRI, Redlands, CA, USA) and evidence of spatial clustering of profiles with given numbers of TR in RR1-P97 locus was assessed using the Bernouilli model of the spatial scan 
statistic (Kulldorff and Nagarwalla, 1995), implemented using the SaTScan software version 9.1.1. The relationship between the $\mathrm{TR}$ in the two loci was explored using non-parametric methods (Spearman correlation and Mann-
Whitney tests) using the SPSS software V.22 (IBM Inc., Chicago, IL, USA). The Simpson's index of diversity (D) for MLVA types was calculated using the Hunter-Gaston method (Hunter and Gaston, 1988).

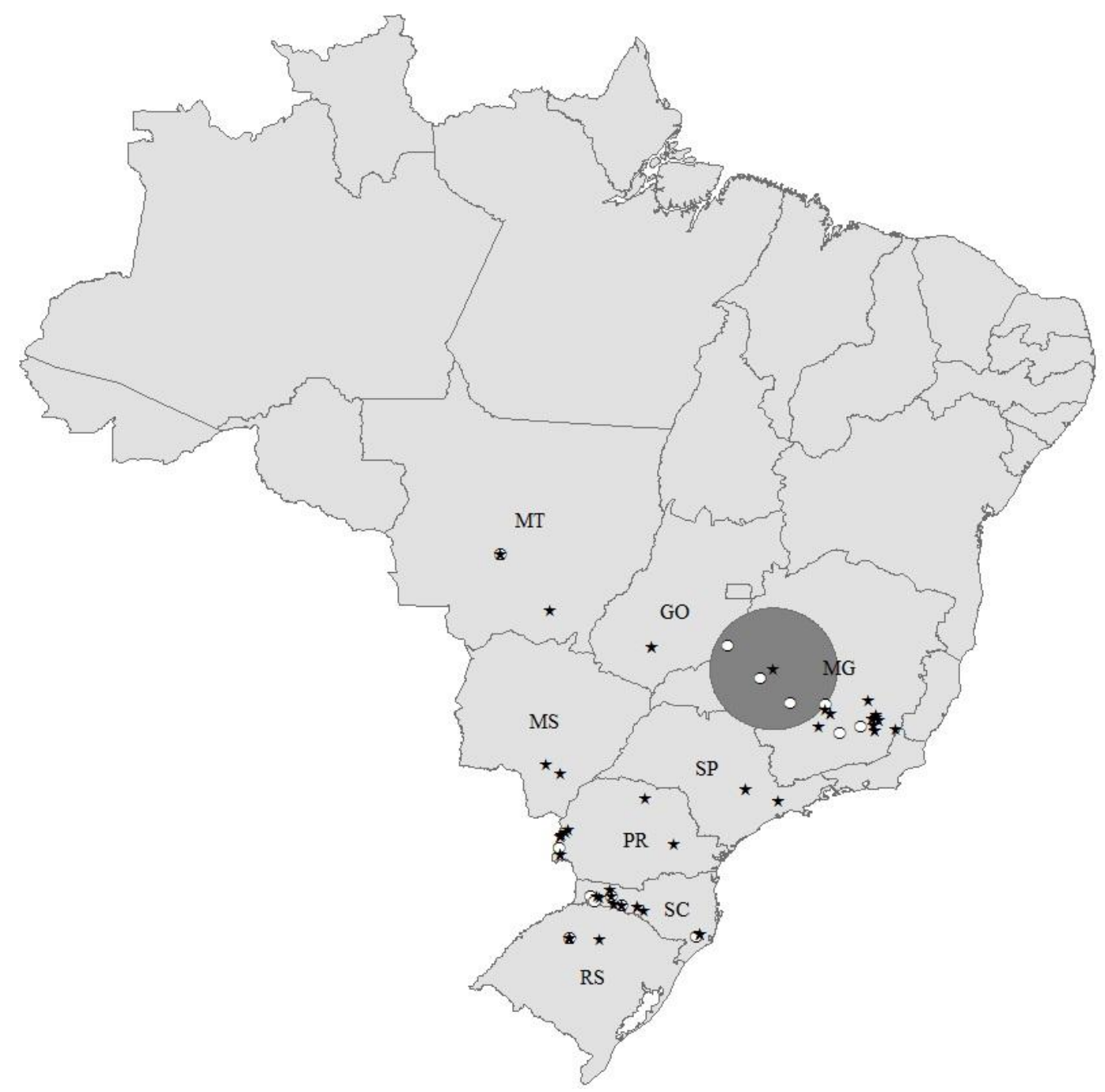

Figure 1. Distribution of MLVA types observed in 63 farms in Brazil. Repeat region 1 (RR1) P97 was categorized as high ( $\geq 8$ tandem repeats, black stars) and low ( $<8$ tandem repeats, white circles). Representation of the MLVA types on the map is based on the actual herd location. The gray circle represents a significant $(\mathrm{P}=0.05)$ cluster of MLVA types with a low number of tandem repeats in RR1 P97 (observed to the expected ratio of 4.22). States identified with the two letter code are the most important areas of swine production in Brazil: Goiás (GO), Minas Gerais (MG), Mato Grosso (MT), Mato Grosso do Sul (MS), Paraná (PR), Rio Grande do Sul (RS), São Paulo (SP) and Santa Catarina (SC).

A total of 94 samples tested positive for $M$. hyopneumoniae and were further typed, yielding 39 MLVA unique types. One pattern (12-14) accounted for $32.9 \%$ of the samples. For the purpose of the spatial analysis, only unique
MLVA types per site (farm) were considered ( $\mathrm{n}$ =76). MLVA types with high $(\geq 8)$ TR in RR1P97 were more abundant (61/76) and more widely distributed across the 84 sampled population, while types with low $(<8)$ TR were 
found in $19.7 \%$ of the samples and were located in two geographical areas, one of which included a significant $(\mathrm{P}=0.05)$ cluster of samples, with an observed to expected ratio of 4.22 (Figure 1). Most farms (49/63, 77.7\%) submitted samples that yielded only high TR in RR1-P97, while 13 farms $(20.6 \%)$ submitted samples in which only low TR RR1-P97 were detected. A combination of both high and low TR in RR1-P97 was identified in one farm only (Table 1).

A significant negative correlation (Spearman $r h o=-0.26 ; \mathrm{P}=0.022$ ) between TR in RR1-P97 and in RR3-P146 was observed. Samples with low TR in RR1-P97 showed a median of 26 TR in RR3-P146, while samples with high TR in RR1-P97 had a median of 15 TR in RR3-P146 (Mann-Whitney test, $\mathrm{P}=0.025$ ).

A high heterogeneity of $M$. hyopneumoniae was observed in the sampled population, with 39 MLVA types from 76 farms ( $D=0.92)$. An identical MLVA type in a majority of the farms $(33.3 \%, 21 / 63)$ could indicate a common source of infection. However, no information about the potential epidemiological connections between affected herds was available, thus the source of infection and mode of spread of the $M$. hyopneumoniae variants among herds are unknown. While MLVA types with high TR in RR1-P97 were widely distributed, farms in which only types with low TR in RR1-P97 were found were less abundant and clustered (Figure 1), which could suggest horizontal spread or exposure to a common local source. Variants with low TR in RR1-P97 may have an impaired adhesion capacity and therefore a decreased infectivity. Still, here low TR in RR1-P97 MLVA types were the only types found in $20.6 \%$ of the farms. Therefore, our results suggest that M. hyopneumoniae variants from Brazil with low TR in RR1-P97 could still be infectious, given that they were the only $M$. hyopneumoniae variants detected in certain clinically affected systems. The negative association of TR in RR1P97 with in RR3-P146 may suggest a possible compensatory mechanism that would allow the bacterium to keep its full adhesion capacity even after the reduction of TR in RR1-P97. However, further studies should be performed to confirm this hypothesis. The results obtained in this investigation will contribute to understand the epidemiology and impact of $M$. hyopneumoniae in the main production areas in Brazil, one of the largest pig producing countries in the world.

Keywords: Adhesion, VNTR, MLVA, swine, enzootic pneumonia

\section{RESUMO}

Diversidade genética de Mycoplasma hyopneumoniae tem sido relatada em análise múltipla de repetições em tandem em número variável (MLVA). O objetivo deste estudo foi descrever a distribuição espacial e a heterogeneidade genética de tipos de M. hyopneumoniae no Brasil, bem como investigar a correlação entre regiões de repetição 1 (RR1) e 3 (RR3) de duas adesinas importantes (P97 e P146). Foram identificados 39 tipos de MLVA baseados no número de repetições em tandem em P97 RRI e RR3 P146. A correlação negativa significativa (Spearman's rho $=-0,26 ; P=0,022)$ entre P97 RRI e RR3 P146 foi observada, o que sugere um possível mecanismo compensatório que permitiria a bactéria manter a sua capacidade de adesão. Os resultados contribuem para compreender a epidemiologia das M. hyopneumoniae no quarto maior país produtor de suínos do mundo.

Palavras-chave: adesina, VNTR, MLVA, suíno, pneumonia enzoótica

\section{ACKNOWLEDGMENTS}

Lucas Dos Santos was supported by Capes Foundation, Ministry of Education of Brazil (proc. No: BEX17617/12-0) and Fundação de Amparo à Pesquisa do Estado de Minas Gerais FAPEMIG. M.A.S.Moreira was supported by CNPQ.

\section{REFERENCES}

BOGEMA, D.R.; DEUTSCHER, A.T.; WOOLLEY, L.K. et al. Characterization of cleavage events in the multifunctional cilium adhesin Mhp684 (P146) reveals a mechanism by which Mycoplasma hyopneumoniae regulates surface topography. MBio, v.3, 2012. 
FERREIRA, H.B.; CASTRO, L.A. A preliminary survey of $M$. hyopneumoniae virulence factors based on comparative genomic analysis. Genet. Mol. Biol., v.30, p.245-255, 2007.

HUNTER, P.R.; GASTON, M.A. Numerical index of the discriminatory ability of typing systems: an application of Simpson's index of diversity. J. Clin. Microbiol., v.26, p.2465-2466, 1988.

KULLDORFF, M.; NAGARWALLA, N. Spatial disease clusters: detection and inference. Stat. Med., v.14, p.799-810, 1995.

MEBUS, C.A.; UNDERDAHL, N.R. Scanning electron microscopy of trachea and bronchi from gnotobiotic pigs inoculated with Mycoplasma hyopneumoniae. Am. J. Vet. Res., v.38, p.12491254, 1977.

MINION, F.C.; ADAMS, C.; HSU, T. R1 region of $\mathrm{P} 97$ mediates adherence of Mycoplasma hyopneumoniae to swine cilia. Infect. Immunol., v.68, p.3056-3060, 2000.
RAZIN, S. Adherence of pathogenic mycoplasmas to host cells. Biosci. Rep., v.19, p.367-372, 1999.

SANTOS, L.; SREEVATSAN, S.; TORREMORELL, M. et al. Genotype distribution of Mycoplasma hyopneumoniae in swine herds from different geographical regions. Vet. Microbiol., v.175, p.374-81, 2015.

THACKER, E.; MINION, F. Mycoplasmal diseases. In: ZIMMERMAN, J.; KARRIKER, L.; RAMIREZ, A. et al. (Eds.) Diseases of swine. 10.ed. New Jersey: Wiley \& Sons, 2012. p.779-788.

WILTON, J.L.; SCARMAN, A.L.; WALKER, M.J.; DJORDJEVIC, S.P. Reiterated repeat region variability in the ciliary adhesin gene of Mycoplasma hyopneumoniae. Microbiology, v.144, p.1931-1943, 1998. 